\title{
UN DEPOZIT DE SILEXURI DESCOPERIT ÎN AȘEZAREA GUMELNIȚEANĂ DE LA GeAngoești, JUD. DÂMBOVIȚA
}

\author{
ANA ILIE, \\ LOREDANA NIȚĂ
}

\section{REZUMAT:}

În cursul cercetărilor de amploare desfășurate în campania anului 2018 în tell-ul de la Geangoești, care au dus la dezvelirea jumătății sudice a așezării eneolitice, a fost descoperit un mic depozit de lame de silex. În acest articol sunt prezentate detaliat atât contextul de descoperire, cât și depozitul, integrate într-un cadru mai larg, al unui palier cronologic unde astfel de situații nu sunt rare.

\section{ABSTRACT: A FLINT CACHE DISCOVERED IN THE GUMELNIȚA SETTLEMENT OF GEANGOEŞTI, DÂMBOVIȚA COUNTY}

The archaeological research during the 2018 season uncovered, in the southern half of the Eneolithic tell at Geangoești, a small cache of flint blades. This article presents both the discovery context of the cache and its composition, as well as its larger chronological framework of similar and not infrequent finds.

CuvinTE CHEIE: depozit, lame de silex, Eneolitic, Cultura Kodjadermen-Gumelnița-Karanovo VI, Geangoești.

KEYwORDS: cache, flint blades, Copper Age, Kodjadermen-Gumelnița-Karanovo VI culture, Geangoești.

\section{Introducere}

Studiile din ultima vreme, care au drept subiect ansamblurile industriei litice abordate în perspectivă diacronică, acoperind palierul cronologic și cultural al culturii Kodjadermen-Gumelnița-Karanovo VI (în continuare K-G-K VI), permit nuanțarea înțelegerii complexității comunităților neo-eneolitice, atât prin modul de organizare a producției, gama de produse obținute, cât și prin funcțiile pe care le deține o tehnică sau alta în obținerea unor tipuri specifice de produse. Mai mult decât atât, se fac pași importanți în înțelegerea posibilelor modele de distribuție ale producției de utilaj litic.

Analizele tipologice și tehnologice ale pieselor litice provenind din diverse așezări gumelnițene de la nord de Dunăre, deși încă rare în peisajul bibliografic, conturează două-trei tipuri de producții. O producție locală, acolo unde surse de materie primă sunt la îndemână ${ }^{1}$, și o producție specializată, din materie primă definită, de-a lungul timpului, drept silex balcanic ${ }^{2}$, ulterior identificată drept „,chert Ludogorie”, tip Ravna, iar în procente mult mai mici, de tip Kriva Reko sau silex moesic ${ }^{3}$, ale cărei piese circulă în vastul spațiu cultural K-G-K VI și acoperă nevoi diverse ale comunităților gumelnițene.

\footnotetext{
1 Niţă, Frînculeasa 2005; Furestier, Mihail 2011; Furestier et al. 2017.

2 Comșa 1975.

3 Gatsov, Nedelcheva, Nacev 2012, 39-40; Dobrescu 2017, 230-231.
} 
Cea de-a treia formă a fost afirmată pentru industria litică de la Atmăgeaua Tătărască și presupune, având în vedere prezența în toate nivelurile culturale din tell-urile aparținând tuturor fazelor culturii Gumelnița, a topoarelor din silex, existența unei producții laminare locale, ce ar permite obținerea de lame de până la 15-19 cm lungime, realizate prin percuție directă dură sau indirectă, dar utilizând materie primă din sursele din sudul Dunării. Astfel de topoare au fost întâlnite frecvent și la Pietrele Gorgana, mai rar în așezările de la Căscioarele - Ostrovel, Sultana - Malu Roșu, Tangîrư 5 , Jilava, Vidra, Vărăști, Radovanu, Gumelnița, Cunești, Cernavodă, Brăilița ${ }^{6}$, Bordușani ${ }^{7}$ și Carcaliu $^{8}$, și au determinat avansarea posibilității existenței unei producții litice sau a unei acumulări de produse în tell-urile de la Dunărea de Jos, de-o parte și de alta a Dunării, dar la distanţă de surse, care ar fi permis distribuţia unor bunuri de prestigiu - lame lungi și topoare de silex, spre periferia nordică a arealului culturii K-G-K VI și mai departe?.

Ideea unui acces mixt la sursele de silex de tip Revno și Kriva Reka din arealul sud dunărean, este susținută și de alți cercetători ${ }^{10}$. Aceasta vizează un import al lamelor foarte lungi, precum și un acces direct la surse şi o producție în sit a lamelor cu dimensiuni cuprinse între $15-19 \mathrm{~cm}$, iar după 4400 cal BC, chiar şi a celor de peste $20 \mathrm{~cm}$ lungime.

Pentru comunităţile din arealul sud-dunărean al culturii K-G-K VI, industria litică cioplită este alcătuită dintr-o producție locală ${ }^{11}$ și din produse variate specializate, care circulă la distanțe mari ${ }^{12}$. Anumite produse sunt exploatate pentru a răspunde unor nevoi utilitare. De exemplu, lamele realizate prin debitaj prin presiune „,by punch” erau exportate la nord de Dunăre și în estul Greciei sau Macedonia. Având în vedere stabilitatea „exportului”, această producție ar fi dus la stabilirea unor rețele economice, precum și la crearea alianțelor în rețea.

Pe de altă parte, lamele lungi obținute prin tehnica presiunii cu levier, descoperite în morminte individuale și în tell-uri, sediul elitelor, sunt acceptate, în unanimitate, ca fiind obiecte de prestigiu. Această producție ar fi circulat mai întâi la sud de Dunăre. Aceste lame cu cât erau mai lungi, complete şi neutilizate, cu atât ar fi fost mai valoroase și ar fi îndeplinit roluri simbolice și sociale deși, la un moment dat, accidental sau intenționat, erau adesea fragmentate și integrate ciclului domestic, transformate in unelte, și nu mai prezintă astfel diferențe notabile față de producția locală. Mai neclară este considerată a fi situația lamelor obținute prin presiune directă (,standing pressure"), aflate din punct de vedere dimensional între cele simbolice și cele utilitare ${ }^{13}$.

În acest context, notăm apariţia la sfârşitul eneoliticului, a depozitelor de piese litice, de podoabe, de piese grele din cupru, de topoare din piatră șlefuită ${ }^{14}$; în studiul de față ne interesează cele care conțin doar piese de silex. La modul general, depozitele de artefacte sunt considerate a fi categorii speciale de descoperiri, indicând atenția particulară oferită acestor piese, legată de o valoare reală, economică sau cultural - mitologică, de o poveste personală sau chiar anticipând o viitoare utilizare. În toate situațiile, erau considerate prețioase de către deținători; mai mult, depunerile în context funerar ale producției de lame mari din arealul culturii K-G-K VI sunt interpretate ca având funcție votivă şi sacră ${ }^{15}$.

În arealul nord-dunărean al culturii K-G-K VI, depozite de piese de silexuri sunt menționate în așezările tell, precum cel de la Pietrele. Aici au fost descoperite nu mai puțin de șapte astfel de depozite ${ }^{16}$, cărora li se adaugă depozitul provenind din săpăturile vechi ${ }^{17}$. La Urlați, o așezare de suprafață, sunt menționate patru depozite de silex ${ }^{18}$, în tellurile de la Vlădiceasca - Gherghelăul Mare sunt amintite trei depozite ${ }^{19}$, la Gumelnița unul ${ }^{20}$, iar altul la Chitila ${ }^{21}$. $\mathrm{Nu}$ este exclus ca lamele lungi, identificate în tell-urile de la nord de Dunăre, la Căscioarele, Vidra, Ulmeni și

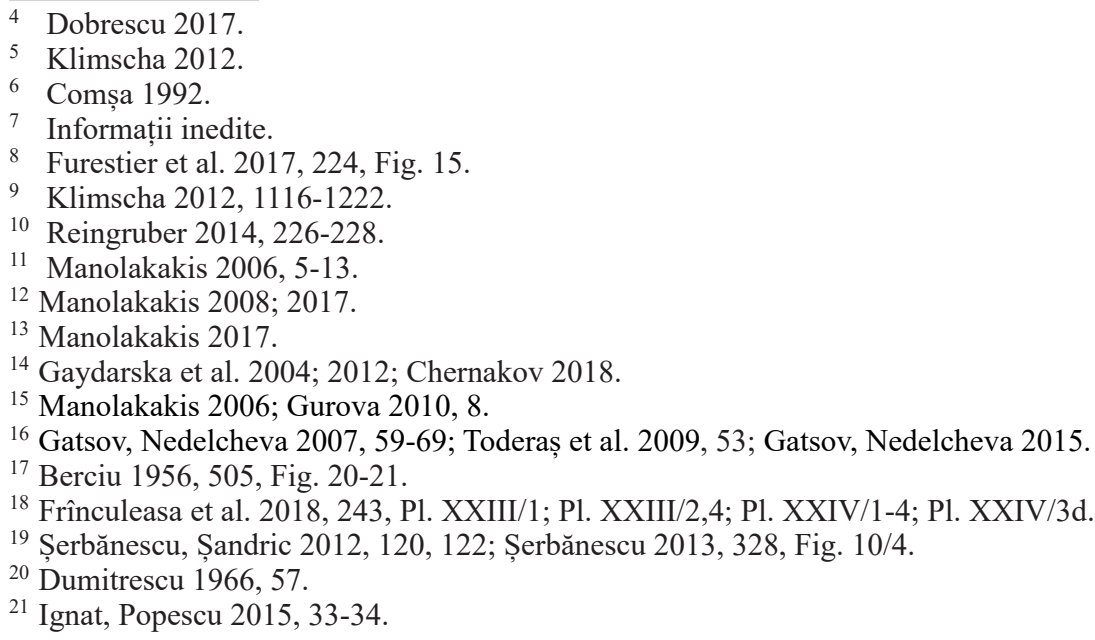

${ }^{21}$ Ignat, Popescu 2015, 33-34. 
Sultana ${ }^{22}$, să provină din depozite, rămase nepublicate. Acestor situații li se adaugă descoperirile izolate, cum ar fi depozitele de la Băbăița ${ }^{23}$, Leșile ${ }^{24}$, București - Străuleștiti ${ }^{25}$, încadrate aceleiași perioade. Astfel de depozite apar și la sud de Dunăre: Azmak, Bikovo - Denevo Moghila, Bulgarene, Hotnica, Kavonova, Provadia, Petka Karovelova, Ruse, Sava, Smyadova, și Sushina ${ }^{26}$. De asemenea, există semnalări ale unor depozite de silexuri încă din faza Spanţov a culturii Boian (vezi depozitele descoperite la Radovanu - La Muscalu ${ }^{27}$ ).

\section{Contextul arheologic al descoperirii}

Începând cu anul 2015, au fost reluate, după 40 de ani, cercetările în situl Geangoești, punct Hulă, comuna Dragomirești, jud. Dâmbovița. Situl, o așezare tell atribuită culturii K-G-K VI, este amplasat la aproximativ 2 km est de râul Dâmbovița, în zona Câmpiei Înalte a Târgoviștei, dar la contactul acesteia cu Subcarpații (Pl. I/1-3).

În campaniile din anii 2015-2016 au fost efectuate cercetări de evaluare a potențialului arheologic al sitului, în condițiile în care cercetările din campania anului 1960 au afectat cca. $700 \mathrm{~m}^{2}$ din cei cca. $2500 \mathrm{~m}^{2}$ ai așezării, iar informațiile culese printre localnici indicau un fenomen de distrugere sistematică, al cărui scop era recuperarea de „comori”, activități reclamate și în rapoartele și notele de șantier din 1960. Alte obiective avute în vedere erau legate de colectarea de date despre amplitudinea depozitului antropic, dimensiunea sitului și complexitatea situaţiilor arheologice ${ }^{28}$.

Cercetarea a continuat în campaniile din anii 2017-2019, când au fost deschise o serie de sectoare de 6x6 m fiecare, împărțite în două suprafețe, acoperind aproape în întregime jumătatea de sud a așezării de la Geangoești - Hulă (Pl. I/4-5). Situl prezintă o stratigrafie complexă, precum și urme ale unor niveluri în bună parte dispărute, foarte probabil în urma lucrărilor agricole intensive executate în perioada comunistă și câțiva ani după 1989. Aceste mărturii ale unor secvențe de locuire preistorice distruse sunt și sub forma unor șanțuri de fundaţie, surprinse în negativ într-o masă de chirpici $\operatorname{ars}^{29}$ (P1. III).

Această masă de chirpici ars provine de la pereții prăbușiți ai unor locuințe incendiate, care pot fi încadrate, fără dubiu, culturii Gumelnița ${ }^{30}$. Depozitul provine din una din aceste locuințe incendiate. În colțul de NE al sectorului 44 se păstrează o parte din colțul de SE al locuinței nr. 4, care și-a încetat funcția iniţială într-un incendiu violent. Acesta a dus inclusiv la zgurificarea pereților locuinței în această zonă (Pl. II).

Latura de vest a locuinței a fost distrusă de șanțurile de fundație ale orizonturilor de locuințe posterioare - Cx. 118 - Cx. 144. De asemenea, aceste complexe, precum și groapa modernă Cx. 143, au dus la distrugerea laturii sale de S (Pl. III). Nu avem date despre colțul de SE al locuinței surprins în martorul de $2 \mathrm{~m}$ lățime lăsat între sectoarele din zona de SV și cele din zona de SE ale așezării, iar cele mai relevante observaţii asupra acestei locuințe au fost realizate în sectorul 54, în campania anului $2019^{31}$.

Lamele au fost descoperite împreună, depozitate într-un vas (Pl. IV/a-b). Incendiul care a mistuit casa a condus la arderea secundară a vasului (vas 27) în care se afla micul depozit, precum și la fragilizarea pieselor din silex, care s-au fragmentat în momentul prelevării. Unele piese au putut fi restaurate cu multă atenție (Pl. IV/c-d; Pl. V) pe când altele au fost afectate irecuperabil (Pl. VI/1, 3-5).

Vasul, de dimensiuni mici, este din categoria celor de uz comun, cu gât înalt și umăr bombat, bază tronconică, cu două torți, dispuse simetric în zona umărului. Buza este lustruită la exterior și interior, corpul este îngrijit netezit la interior şi decorat cu barbotină organizată în vârci oblice, care se învârtesc în jurul corpului de la umăr spre bază. Acesta se afla, întreg, dar răsturnat, pe podeau locuinței.

\footnotetext{
22 Reingruber 2014, Tab. 8.

${ }^{23}$ Torcică 2011.

${ }^{24}$ Nania 1965.

${ }^{25}$ Ignat, Popescu 2015.

${ }^{26}$ Avramova 2008, 212; Gurova 2010, 5-8; Gurova 2011, 185; Gaydarska et al. 2012, Tab 2; Ștefan 2012, Tab. 2; Gurova, Chabot, Chohadzdiev 2016.

${ }^{27}$ Comșa 1990, 30.

${ }^{28}$ Cîrstina, Olteanu, Ilie 2016.

${ }^{29}$ Ilie, Cîrstina, Ilie 2019.

${ }^{30}$ Ilie et al. 2020

${ }^{31}$ Ilie et al. 2020.
} 

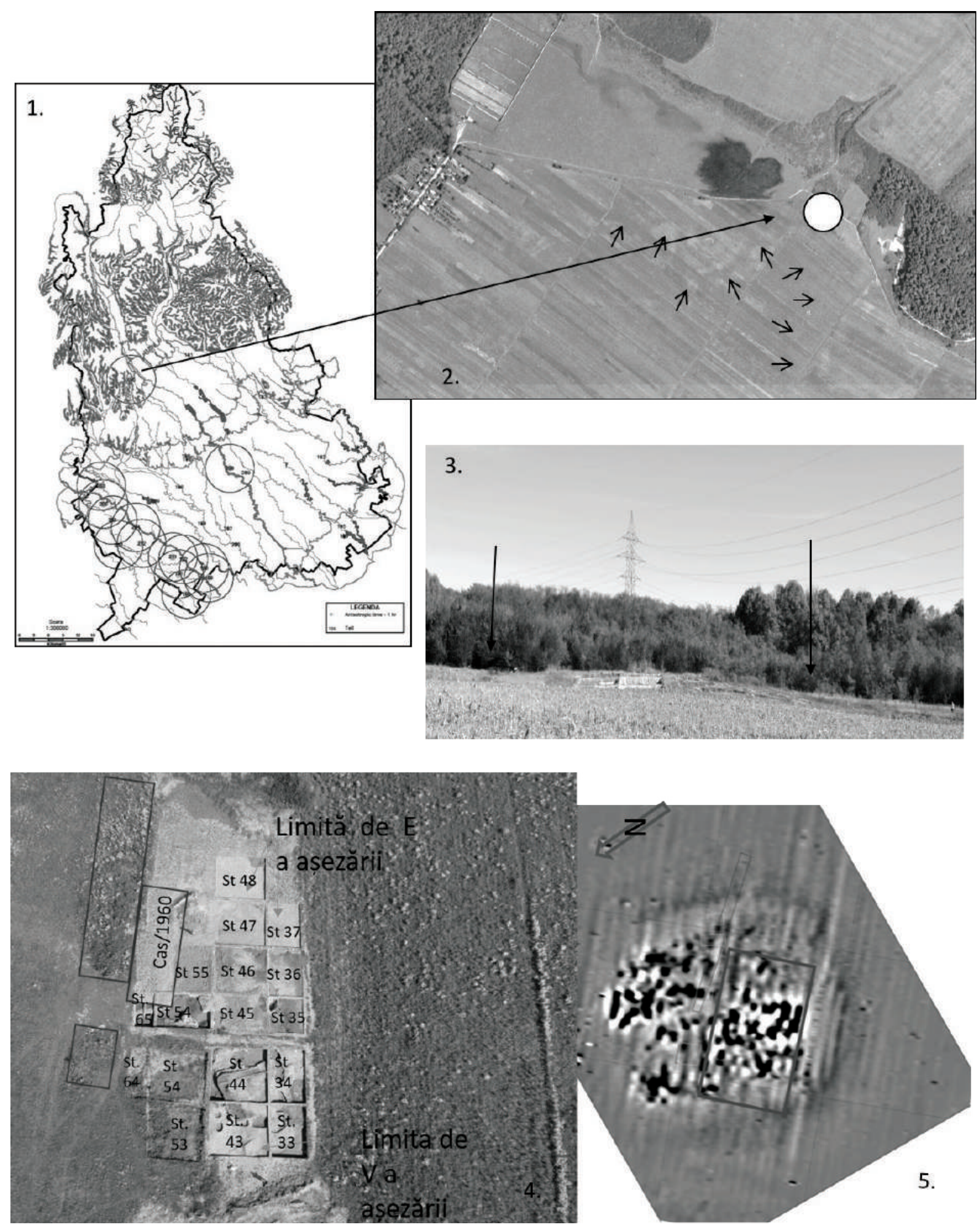

Planșa I. 1. Harta izometrică a județului Dâmbovița pe care sunt marcate siturile atribuite culturii Gumelnița (autor B. Ilie); 2. Ortofotoplan cu zona Geangoești, pe care sunt evidențiate tell-ul și un paleocanal al râului Dâmbovița; 3. Fotografie dinspre SE asupra tell-ului; 4. Imagine de sus asupra suprafeței deschise în tell-ul de la Geangoești (zbor cu drona realizat de B. Ilie, 2018); 5. Imaginea geomagnetică a sitului (după Micle, Stavilă 2018, fig. 8), pe care sunt marcate suprafețele deschise în campaniile 2016 și 2017-2019. 


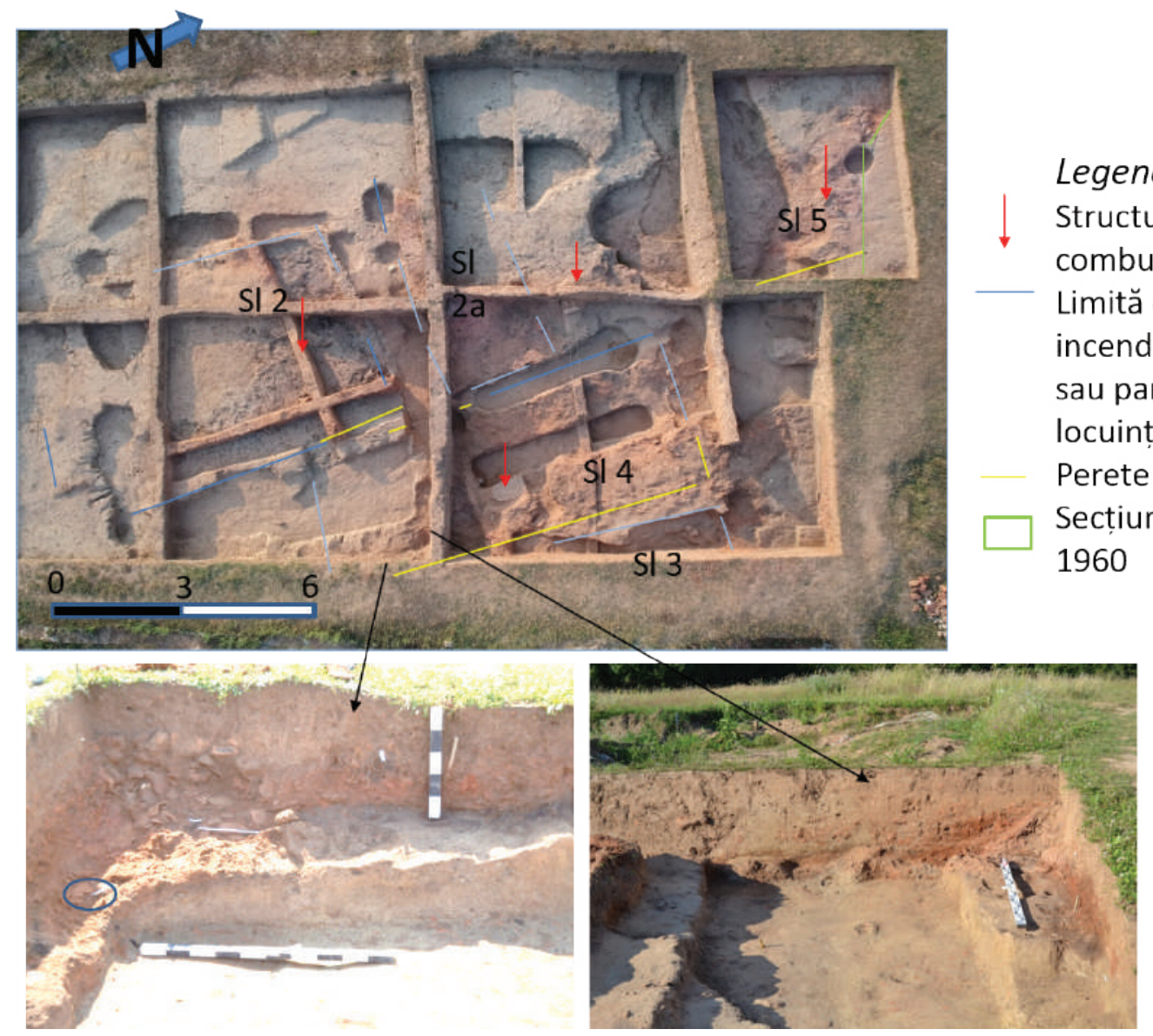

Planșa II. Imagine de sus asupra zonei de SV a tell-ului (zbor cu drona realizat de B. Ilie, 2019), pe care sunt marcate locuințele identificate în campania anului 2019, și fotografii de detaliu ale profilelor de N și E, st. 44, pe care se observă distrugerea locuinței nr. 4, Us. 570 (autor A. Ilie).

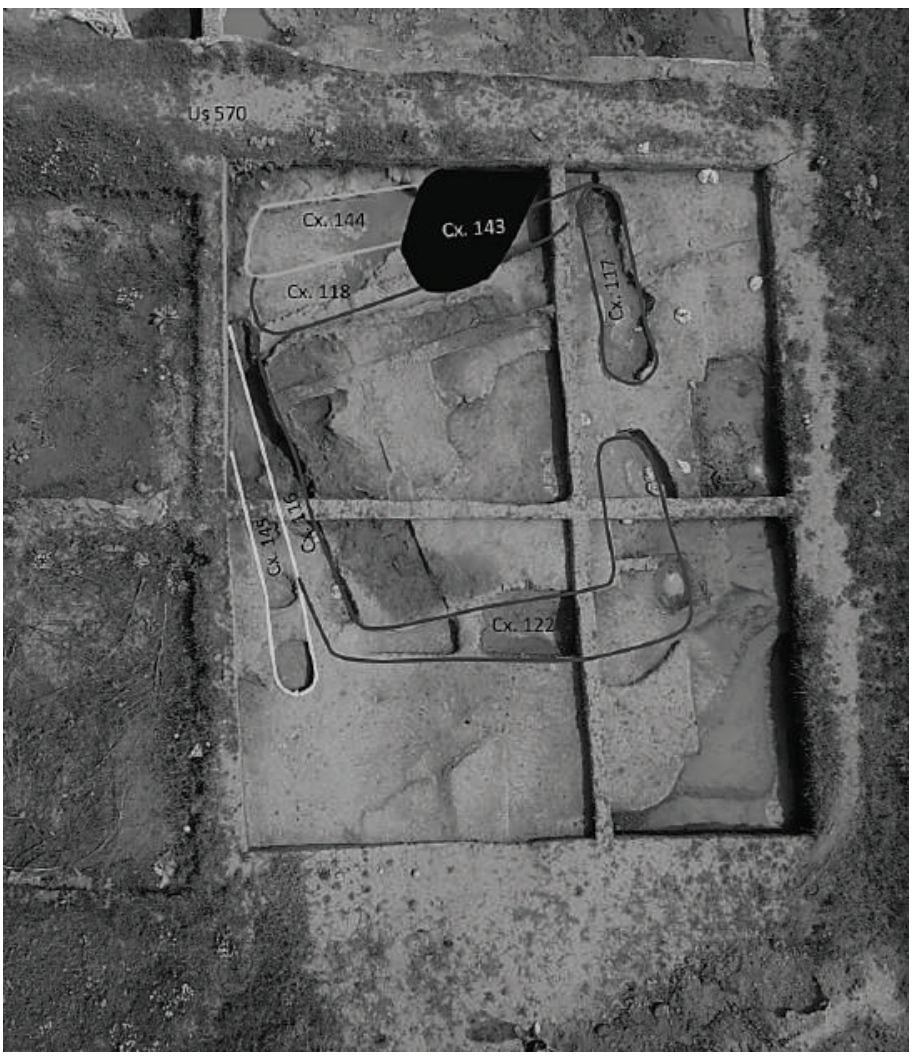

Planșa III. Imagine de sus (zbor cu drona realizat de B. Ilie, 2018) pe care sunt marcate principalele complexe adâncite identificate în zona de SV a tell-ului. 


\section{Descrierea depozitului de piese}

Eșantionul include nouă piese și fragmente litice calcinate din silex (Tab. 1). Acestea sunt suporturi laminare complete, distale, meziale și unul proximal, aparținând etapei de plein débitage a secvenței operatorii.

Aparent, trei din piesele complete (Pl. V/1-3), o piesă mezială și piesele distale (Pl. VI/1,3,4) constituie desprinderi succesive de pe același nucleu. Ultima din piesele complete (Pl. V/4) și piesa proximală (Pl. VI/2) par să fi provenit din alt nucleu, dintr-un alt tip de silex.

Ulterior producției, nu au fost efectuate modificări sau amenajări ale suporturilor obținute.

Lamele complete au taloane netede, late de $0,6-0,7 \mathrm{~cm}$, profil concav, secțiune transversală trapezoidală sau triunghiulară și dimensiuni de 7,1-13,9 cm lungime, 1,5-2,5 cm lățime, respectiv 0,4-0,8 cm grosime. Piesele prezintă fracturi și desprinderi de pe suprafețele dorsale și ventrale datorate arderii, dar, în cazul celor fragmentate (P1. VI/1-5), se pot observa și fracturi de natură mecanică, anterioare momentului calcinării.

Ulterior arderii și pierderilor de material, piesele complete de dimensiuni mari cântăresc între 18 și 26 grame, în timp ce greutatea celor fragmentate variază între 4 și 11 grame. Niciuna dintre piese nu conservă urme de folosire macro- sau microscopice.
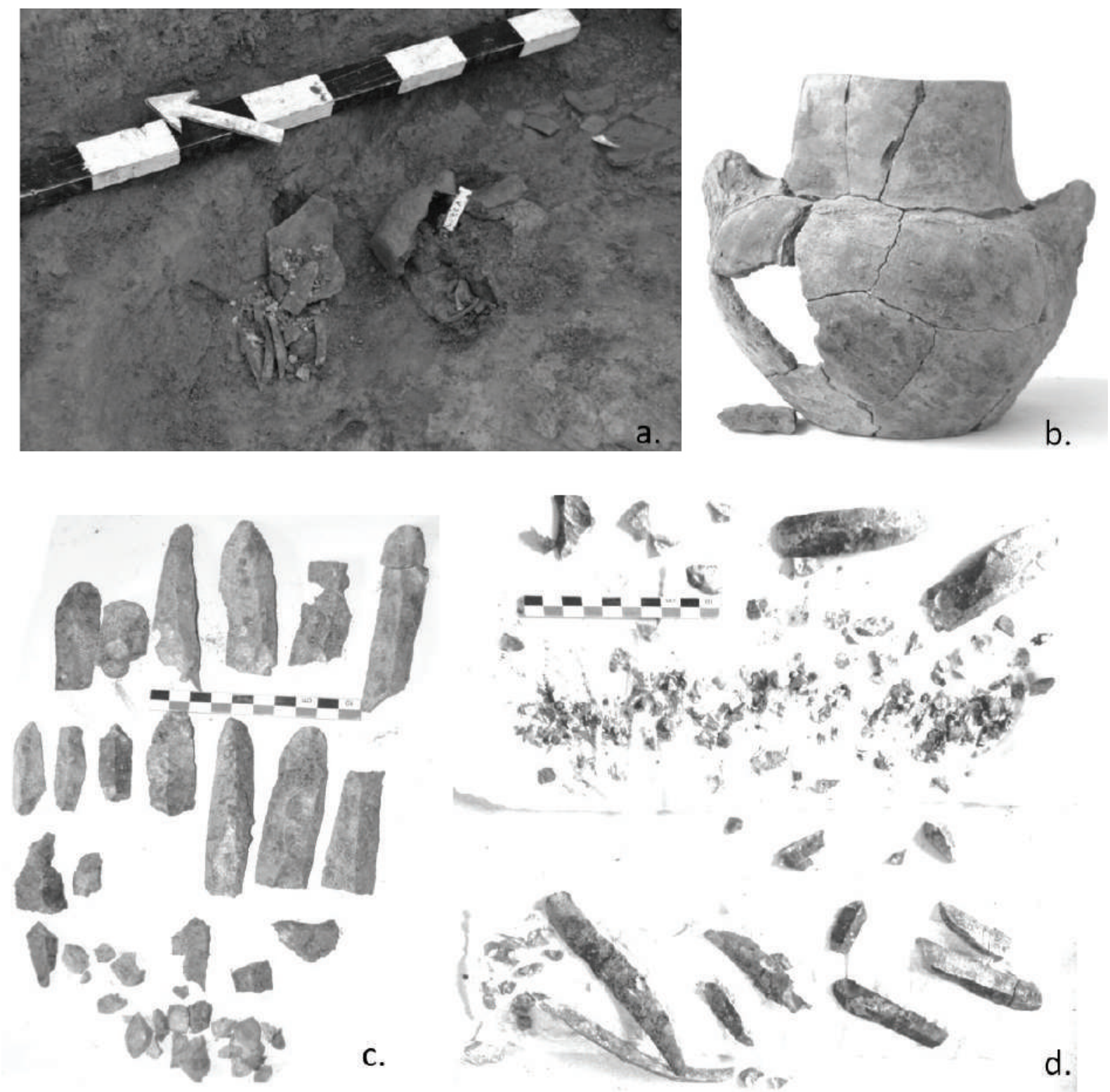

Planșa IV. a. Fotografie din tipul prelevării vasului în care a fost descoperit depozitul de silexuri; b. Fotografie cu vasul restaurat; c-d. Fotografii cu piesele din silex, imediat după descoperire și din timpul restaurării (foto A. Ilie). 

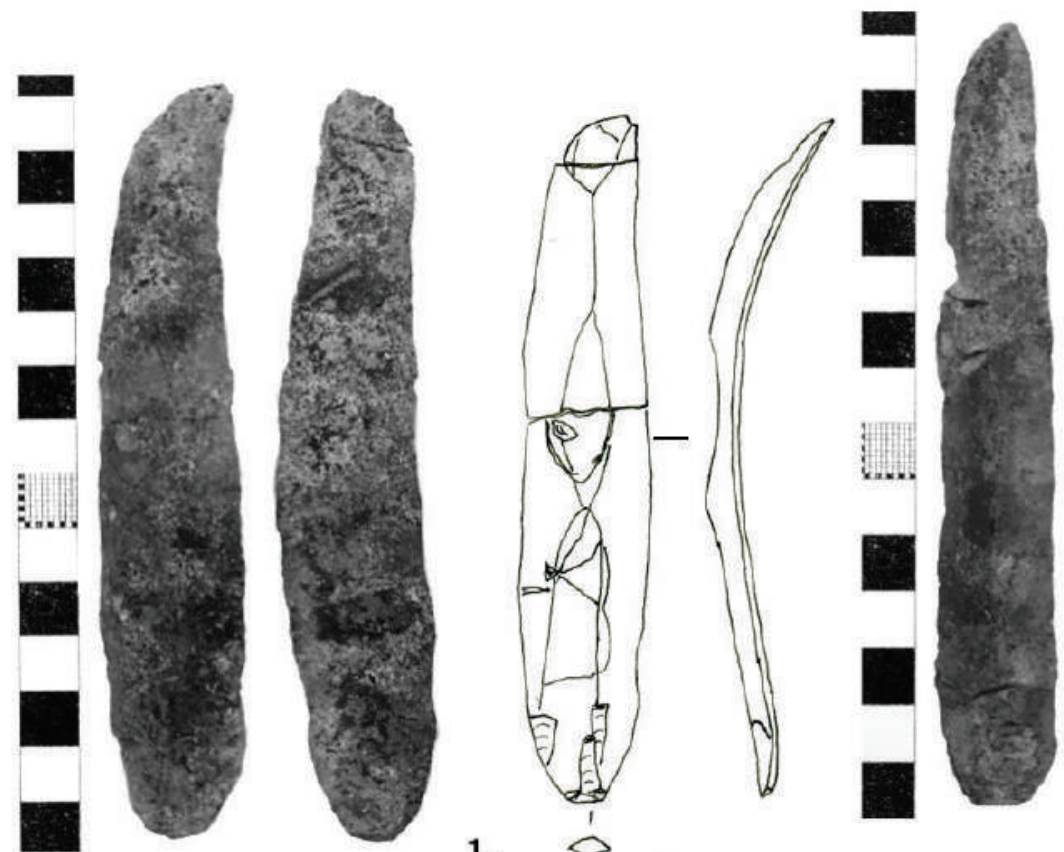

1. $\stackrel{1}{\circ}$
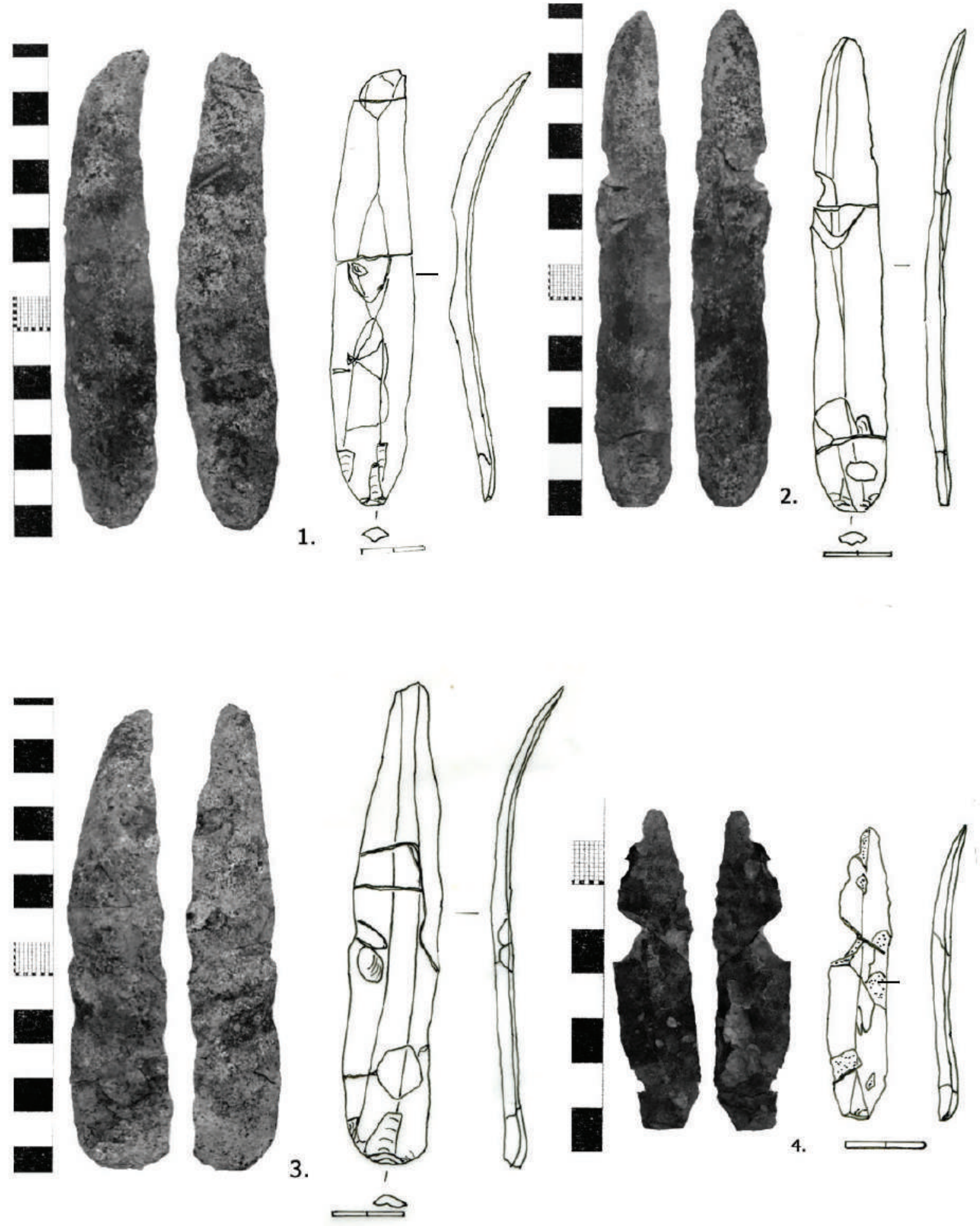

Planșa V. 1-4. Piese din silex din depozitul de la Geangoești (v. 27), colecția de Arheologie a Complexului Național Muzeal „Curtea Domnească” Târgoviște, inv. 356/2018 (foto L. Niță, desene A. Ilie). 

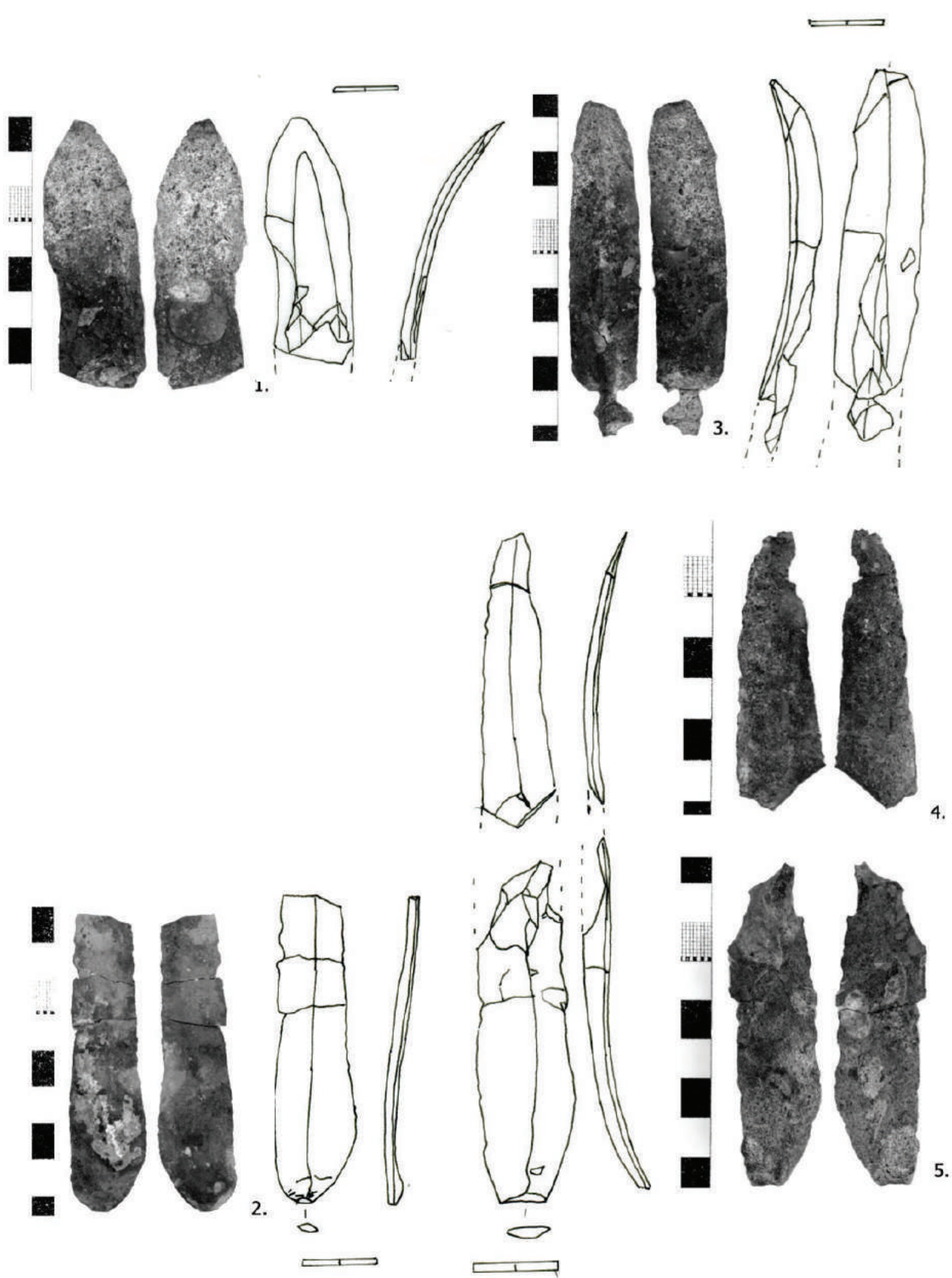

Planșa VI. 1-4. Piese din silex din depozitul de la Geangoești (v. 27), colecția de Arheologie a Complexului Național Muzeal „Curtea Domnească” Târgoviște, inv. 356/2018 (foto L. Niță, desene A. Ilie). 
Tabelul 1. Conținutul și descrierea depozitului de lame din silex de la Geangoești, locuința nr. 4.

\begin{tabular}{|c|c|c|c|c|c|c|c|c|}
\hline $\begin{array}{l}\text { Nr. } \\
\text { crt. }\end{array}$ & $\begin{array}{l}\text { Tip de } \\
\text { piesă }\end{array}$ & $\begin{array}{c}\text { Stare de } \\
\text { conservare }\end{array}$ & Descriere & $\begin{array}{l}\text { L. } \\
\text { max. } \\
(\mathbf{m m})\end{array}$ & $\begin{array}{l}1 . \\
\max . \\
(\mathbf{m m})\end{array}$ & $\begin{array}{l}\text { G. } \\
(\mathrm{mm})\end{array}$ & $\begin{array}{l}\text { Gr. } \\
\text { (g) }\end{array}$ & $\begin{array}{l}\text { Trimitere } \\
\text { la ilustrație }\end{array}$ \\
\hline 1. & Lamă & $\begin{array}{l}\text { Restaurată } \\
100 \%\end{array}$ & \begin{tabular}{|l} 
Arsă \\
Gri alburiu \\
Silex cu fosile
\end{tabular} & 139 & 25 & 8 & 26,7 & Pl. 5/1 \\
\hline 2. & Lamă & $\begin{array}{l}\text { Restaurată } \\
100 \%\end{array}$ & \begin{tabular}{|l|} 
Arsă \\
Gri alburiu \\
Silex cu fosile \\
\end{tabular} & 132 & 24 & 6 & 19,4 & Pl. 5/2 \\
\hline 3. & Lamă & $\begin{array}{l}\text { Restaurată } \\
100 \%\end{array}$ & \begin{tabular}{|l} 
Arsă \\
Gri alburiu \\
Silex cu fosile
\end{tabular} & 139 & 21 & 7 & 18,8 & Pl. $5 / 3$ \\
\hline 4. & Lamă & $\begin{array}{l}\text { Restaurată } \\
100 \%\end{array}$ & $\begin{array}{l}\text { Arsă } \\
\text { Gri cenuşiu }\end{array}$ & 71 & 15 & 4 & 3,9 & $\mathrm{Pl} .5 / 4$ \\
\hline 5. & Lamă proximală & $\begin{array}{l}\text { Restaurată } \\
100 \%\end{array}$ & $\begin{array}{l}\text { Arsă } \\
\text { Gri cenuşiu }\end{array}$ & 81 & 21 & 4 & 7,4 & Pl. $6 / 2$ \\
\hline 6. & Lamă mezială & $\begin{array}{l}\text { Restaurată } \\
60 \%\end{array}$ & $\begin{array}{l}\text { Arsă } \\
\text { Gri alburiu } \\
\text { Silex cu fosile }\end{array}$ & 97 & 20 & 7 & 11,9 & Pl. 6/3 \\
\hline 7. & Lamă mezială & $\begin{array}{l}\text { Restaurată } \\
50-60 \%\end{array}$ & \begin{tabular}{|l|} 
Arsă \\
Gri alburiu \\
Silex cu fosile
\end{tabular} & 82 & 24 & 5 & 10,4 & Pl. $6 / 5$ \\
\hline 8. & Lamă distală & $\begin{array}{l}\text { Restaurată } \\
50 \%\end{array}$ & \begin{tabular}{|l} 
Arsă \\
Gri alburiu \\
Silex cu fosile
\end{tabular} & 75 & 26 & 5 & 10.3 & Pl. 6/1 \\
\hline 9. & Lamă distală & $\begin{array}{l}\text { Restaurată } \\
40 \%\end{array}$ & \begin{tabular}{|l} 
Arsă \\
Gri alburiu \\
Silex cu fosile
\end{tabular} & 68 & 18 & 4 & 3,7 & Pl. 6/4 \\
\hline
\end{tabular}

\section{Concluzii}

Fără a nega posibilele semnificații simbolice/mitologice ce ar fi putut fi asociate acestui material - silexul ${ }^{32}$, credem că trebuie studiat mai ales prin prisma unui acces al comunităților gumelnițene la aceste resurse, cu atât mai mult cu cât unele, cum este cea de la Geangoești, sunt situate la cca. 250 - $300 \mathrm{~km}$ depărtare de sursele cele mai frecvent utilizate în diferitele faze ale culturii Gumelnița, și anume chert-ul de tip Ravna. Aceaste distanțe implică un proces de achiziție, distribuție, eventual redistribuție, și chiar un control al acestei materii prime și produselor semifinite sau finite, indispensabile activităţilor cotidiene. În acest sens, al unei prezențe în scop pragmatic a depozitelor de silexuri în așezările gumelnițene de la nord de Dunăre, considerăm că pledează și existența depozitului de la Geangoești:

- piesele au fost descoperite laolaltă, stocate într-un vas, în interiorul unei locuințe; șapte lame par să provină din același nucleu, iar ultimele două, din altă sursă de materie primă, toate fără urme de utilizare.

- materia primă/nucleele/produsele finite provin, cel mai probabil, din sursele din platforma pre-balcanică.

- depozitul se află într-o locuință despre care considerăm că a fost incendiată intenționat. Pe de altă parte, dar în același sens al unui control al acestei resurse, considerăm a fi și informația că locuința nr. 4 este singura în care am descoperit un astfel de depozit, deși au fost excavate șase locuințe în colțul de $\mathrm{S}-\mathrm{V}$ al așezării, chiar dacă nu toate contemporane.

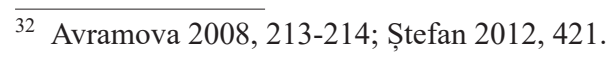


Deși la momentul actual lipsesc analize tehno-tipologice pentru majoritatea depozitelor descoperite la nord de Dunăre, pe baza informațiilor obținute din ilustrații putem bănui că lamele prezintă lungimi cuprinse între 7 și 16 cm și doar arareori depășesc aceste dimensiuni, cum ar fi câteva din depozite de la Pietrele - Gorgana. Analiza celor şapte depozite descoperite în tell-ul de la Pietrele - Gorgana a conturat o ipoteză de lucru foarte interesantă. Astfel, conform specialiștilor ${ }^{33}$, depozitele, având în vedere compoziția acestora - lame neretuşate sau/și unelte, lungimea lamelor, tehnica de producere a lamelor, ar fi mărturia a două tipuri de activități domestice. O formă este cea a depozitelor de lame lungi, cu caracter special acumulate, în scopul de a fi recuperate și folosite mai târziu. O altă formă este aceea a unor rezerve de mici dimensiuni, care asigură un acces rapid, pentru modificarea suporturilor și utilizarea lor în scop domestic. Alte studii adaugă nuanțe noi în înțelegerea acestor depozite, corelând și date topografice şi contextuale ${ }^{34}$. De exemplu, depozitele de silex din tell-ul de la Pietrele au fost identificate doar în locuințe din șirul de N, specializate în măcinare și gătit sau țesut.

În cazul micului tell de la Geangoești, cercetările fiind în desfăşurare, sperăm ca în campaniile de săpături din anii viitori să obținem date noi despre celelalte locuințe din acest nivel din care face parte locuința nr. 4 și, în acest fel, să completăm contextul de descoperire și importanța care trebuie acordată acestui depozit de lame din silex, extinzând analiza asupra întregului ansamblu litic din aşezare.

\section{BibliografiE}

Avramova 2008

Berciu 1956

Chernakov 2018

Cîrstina, Olteanu, Ilie 2016

Comșa 1975

Comșa 1990

Comşa 1992

Dobrescu 2017

Dumitrescu 1966

Frînculeasa et al. 2018

Furestier, Mihail 2011

33 Gatsov, Nedelcheva 2015.
34 Reingruber 2014, 226-228.
Avramova, M., „Special” stones in prehistoric practices: cases from Bulgaria, în Kostov, K.I., Gaydarska, B., Gurova, M. (eds.), Geoarheology and Archeomineralogy, Proceedings of the International Conference, 29-30 October, Sofia, Publishing House „Sf. Ivan Rilski”, Sofia, 2008, 211-215.

Berciu, D., Cercetări şi descoperiri arheologice în regiunea Bucureşti, Materiale și Cercetări Arheologice, 2, 1956, 544-562.

Chernakov, D., A New-Found Hoard of Chalcolithic Heavy Copper Tools from Northeastern Bulgaria, Archeologia Bulgarica, XXII, 2, 2018, 1-13.

Cîrstina, O., Olteanu, Gh., Ilie, A., Raport preliminar sat Geangoești, comuna Dragomirești, jud. Dâmbovița, pct. Hulă, Cronica cercetărilor arheologice din România. Campania anului 2015, 2016, 33-34.

Comşa, E., Silexul de tip „,balcanic”, Peuce, IV, 1973-1975, 5-20.

Comşa, E., Complexul neolitic de la Radovanu, Cultură și Civilizație la Dunărea de Jos, VII, 1990.

Comşa, E., Les haches de silex dans l'aire culturelle Gumelnitza du Sud -Est de la Roumanie, Balcanica, XXIII, 1992, 271-279.

Dobrescu, R., Quelques observations d'ordre technologique et typologique sur les industries litiques découvertes à Atmăgea Tătărească (Sokol, Bulgarie), Materiale și Cercetări Arheologice (S.N.), XVIII, 2017, 227-260.

Dumitrescu, V., Gumelniţa - Sondajul stratigrafic din 1960, Studii şi Cercetări de Istorie veche, 17 (1), 1966, 51-99.

Frînculeasa, A., Preda, B., Garvan, D., Nica, T., Negrea, O., La hotarul nordic al culturii Gumelnița - așezarea de la Urlați (jud. Prahova), Buletinul Muzeului Județean Teleorman, Seria Arheologie, 10, 2018, 237-278.

Furestier, R., Mihail, F., L'industrie lithique taillée de Taraschina, Carozza, L., Bem, C., Micu, C. (eds.), Société et environnement dans la zone du Bas Danube durant le 5ème millénaire avant notre ère, Iași, 2011, 365-383. 
Furestier et al. 2017

Gatsov, Nedelcheva 2007

Gatsov, Nedelcheva, Nacev 2012

Gatsov, Nedelcheva 2015

Gaydarska et al. 2004

Gaydarska et al. 2012

Gurova 2010

Gurova 2011

Gurova, Chabot, Chohadziev 2016

Hansen et al. 2007

Hansen et al. 2012

Ignat, Popescu 2015

Ilie, Cîrstina, Ilie 2019

Ilie et al. 2020

Klimscha 2012
Furestier, R., Mihail, F., Manolakakis, L., Philibert, S., Carozza, L., Micu, C., Les industries lithiques énéolithiques de la Dobroudja du Nord, Materiale şi Cercetări Arheologice (S.N.), XIII, 2017, 213-226.

Gatsov I., Nedelcheva P., Chipped stones, în Hansen S., Toderaş M., Reingruber A., Gatsov I., Georgescu C., Görsdorf J., Hoppe T., Nedelcheva P., Prange M., Wahl J., Wunderlich J., Zidarov P., Pietrele, Măgura Gorgana, Eurasia Antiqua, 13, 2007, 59-69.

Gatsov, I., Nedelcheva, P., Nacev, C., Chipped stones, în Hansen S., Toderaş M., Reingruber A., Wunderlich J., Benecke R., Gatsov I., Marinova E., Müller M., Nachev C., Nedelcheva P., Nowaki D., Räpke A., Wahl J., Zäpke A., Pietrele an der Unteren Donau. Bericht über die Ausgrabunger und Geomorphologishen Untersuchungen im Sommer 2011, Eurasia Antiqua, 18, 2012, 39-40.

Gatsov, I, Nedelcheva P., Flint caches in the Eneolithic settlement Pietrele Măgura Gorgana, România, în Hansen, S., Raczky, P., Anders, A., Reigruber, A., Neolithic and Copper Age between the Carpathian and the Aegean Sea: chronologies and technologies from the $6^{\text {th }}$ to the $4^{\text {th }}$ Millennium BCE. International Workshop Budapest, 2012 Habelt, Bonn, 2015, 295-299.

Gaydarska, B., Chapman, J., Angelova, I., Gurova, M., Yanev, S., Breaking, making and trading: the Omurtag Eneolithic spondylus hoard, Archeologia Bulgarica, VIII, 2, 2004, 11-34.

B. Gaydarska, B., Gurova, M., Chernakov, D., Blake, E., Chapman, J., A place to live, a place to bury and a place to hoard: understanding deposition on and off the Bulgarian tell of Kosharna, Archaeologia Bulgarica, XVI, 2, 2012, 27-58.

Gurova, M., Connotations fonctionnelles des grandes lames chalcolithiques: Example de la Bulgarie, Archaeologia Bulgarica, XIV (2), 2010, 1-10.

Gurova, M., A Late Chalcolithic flint assemblage from the site of Kosharna, Russe District, în Mills, S., Mirea, P. (eds.), The Lower Danube in Prehistory: Landscape Changes and Human Environment Interactions, Proceedings of the International Conference Alexandria, 3-5 November 2010, Editura Renaissance, Alexandria, 2011, 179-196.

Gurova, M., Chabot, J., Chohadzhiev, S., Chalcolithic superblades from Bulgaria: a case study of recently found hoard from Sushina, Bulgarian e-Journal of Archaeology, 6.2, 2016, 165-190.

Hansen S., Toderaş, M., Reingruber, A., Gatsov, I., Georgescu, C., Görsdorf, J., Hoppe, T., Nedelcheva, P., Prange, M., Wahl J., Wunderlich, J., Zidarov, P., Pietrele, Măgura Gorgana, Eurasia Antiqua, 13, 2007, 43-112.

Hansen S., Toderaş M., Reingruber A., Wunderlich J., Benecke R., Gatsov I., Marinova E., Müller M., Nachev C., Nedelcheva P., Nowaki D., Räpke A., Wahl J., Zäpke A., Pietrele an der Unteren Donau. Bericht über die Ausgrabunger und Geomorphologishen Untersuchungen im Sommer 2011, Eurasia Antiqua, 18, 2012, 1-68.

Ignat, T., Popescu, I., Un ansamblu de piese litice descoperit la Străulești, Revista de Cercetări Arheologice și Numismatice, I, 29-41.

Ilie, A., Cîrstina, O., Ilie, B., Raport preliminar - sat Geangoești, comuna Dragomirești, jud. Dâmbovița, pct. Hulă, Cronica Cercetărilor Arheologice din România. Campania anului 2018, 2019, 60-62.

Ilie, A., Cîrstina, O., Ilie, B., Iordache, A., Raport preliminar - sat Geangoești, comuna Dragomirești, jud. Dâmbovița, pct. Hulă, Cronica Cercetărilor Arheologice din România. Campania anului 2019, sub tipar.

Klimscha, F, Des goûts et des couleurs, on ne discute pas. Datation, répartition et valeur sociale des haches en silex de la culture Gumelnița, în Pétrequin, P., Cassen, S., Errero, M., Klassen, L., Sheridan, A., Pétrequin, A.-M. (eds.), JADE. Grandes haches alpines du Néolitique européen, Ve au Ive millénaires av. J.-C., Cahiers de la MSHE Sedoux, $n^{\circ}$ 17, „Dynamique territoriales” $n^{\circ}$ 6, tome 2, Besançon, 2012, 1208-1229. 
Manolakakis 2006

Manolakakis 2008

Manolakakis 2017

Micle, Stavilă 2014

Nania 1965

Niță, Frînculeasa 2005

Reingruber 2014

Șerbănescu 2013

Ștefan 2012

Toderaș et al. 2009

Torcică 2011
Manolakakis, L., Les très grands lames de Varna (Bulgarie): quelle function? Vaquer, J., Briois F., (eds.), Le fin de l'Âge de la pierre en Europe du Sud. Matériaux et productions litiques taillées remarquables dans le Néolitique et le Chalcolithique du Sud de l'Europe, Actes de la table ronde de l'EHESS (Carcasonnes 5-6 septembre 2003), Toulouse, 2006, 5-23.

Manolakakis, L., Open-cast flint mining, long blade production and long-distance exchange: an example from Bulgaria, Allard, P., Bostyn, F., Giligny, F., Lech J. (eds.), Flint Mining in Prehistoric Europe. Interpreting the Archaeological Record, BAR (I.S.), 1891, 2008, 111-121.

Manolakakis, L., So long blades...Materiality and symbolism in the north-eastern Balkan Copper Age, în Manolakakis, L., Schlager, N., Coudart A. (eds.), European Archaeology-Identities and Migration. Hommages à Jean-Paul Demoule. Sidestone Press, Leiden, 2017, 265-284.

Micle, D., Stavilă, A., Geangoești - Hulă, Romania: a Gumelnița settlement on the banks of the Dâmbovița River. Non - Invasive research result, Annales d'Université Valahia Târgoviște, Section d'Archéologie et d'Histoire, XVI, 2, 2014, 33-46.

Nania, I., Două depozite de unelte neolitice descoperite în raionul Costeşti (regiunea Argeş), Studii și Cercetări de Istorie veche, 16, 2, 1965, 311-321.

Niţă, L., Frînculeasa A., Consideraţii asupra materialului litic cioplit descoperit în aşezarea gumelniţeană de la Urlaţi (jud. Prahova), Argesis, XIV, 2005, 41-53.

Reingruber, A., The wealth of the tells: complex settlement patterns and specializations in the West Pontic area between 4600 and 4250 cal BC, în Horejs, B., Mehofer M. (eds.), Western Anatolia before Troy. Proto-Urbanisation in the 4 th Millennium BC? Proceedings of the International Symposium, Kunsthistorischen Museum Wien, Vienna, Austria, 21-24 November, 2012, Austrian Academy of Sciences, Vienna, 2014, 217-242.

Şerbănescu, Şandric 2012 Şerbănescu, D., Şandric, B., Tell-uri eneolitice în regiunea Valea Mostiştei. O privire generală, Morintz, A.S., Kogălniceanu, R. (eds.), Archaeological Debates, $n$ 2: Survey in Archaeology, often a neglected Science, Proceedings of the II Archaeological Symposium, Giurgiu, October $23^{\text {rd }}-26^{\text {th }}, 2011,2012,103-150$.

Șerbănescu, D., Research on the eneolithic Tell of Vlădiceasca, Călărași County, Comșa, A., Bonsall,C., Nikolova, L. (eds.), Facetes of the Past. The Challange of the Balkan Neo-Eneolithic, Proceedings of the International Symposium Celebrating the 85 th Birth Anniversary of Eugen Comșa, 6-12 October 2008, Bucharest, Romania, Editura Academiei Române, București, 2013, 312-335.

Ștefan, E.C., A hoard of flint items from Verbicioara, Romania, Documenta Praehistorica, XXXIX, 2012, 417-423.

Toderaș, M., Hansen, S., Reingruber A., Wunderlich J., Pietrele-Măgura Gorgana: o așezare eneolitică la Dunărea de Jos între 4500 și 4250 î.e.n., Materiale și Cercetări Arheologice (S.N.), V, 2009, 39-90.

Torcică, I., Depozitul de lame de silex descoperite în localitatea Băbăița (jud. Teleorman), Buletinul Muzeului Județean Teleorman, Seria Arheologie, 3, 2011, 133-142.

\section{LIST OF ILLUSTRATIONS}

Plate I. 1. Gumelnița sites in Dâmbovița County - hipsometric map (by B. Ilie); 2. Aerial photography on which is outline the tell from Geangoești and a paleo channel of Dâmbovița River; 3. Geangoești tell - view from SE; 4. Geangoești tell - aerial view of the excavated surface (drone flight by B. Ilie, 2018); 5. The magnetogramme of the Geangoești tell (after Micle, Stavilă 2018, fig. 8) and the 2016 and 2017-2019 excavated areas marked in red and blue. 
Plate II. Geangoești tell - aerial view of the SW area (drone flight by B. Ilie, 2019) and the households discovered during the 2019 fieldwork marked as S1 (up); Northern and Eastern sections of square 44, with details of the destruction level of household $n^{\circ} 4$ (photo A. Ilie) (down).

Plate III. Geangoești tell - aerial view (drone flight by B. Ilie, 2018) and the main features in the SW area of the settlement.

Plate IV. a. In situ discovery context of the flint hoard; b. Restored vessel; c-d. The flint blades during restoration (photo A. Ilie).

Plate V. 1-4. Flint cache blades - Archaeological collection of the „Princiary Court” National Museum Complex, Târgoviște, inventory 356/2018 (photo L. Niță, drawings A. Ilie).

Plate VI. 1-4. Flint cache blades - Archaeological collection of the „Princiary Court” National Museum Complex, Târgoviște, inventory 356/2018 (photo L. Niţă, drawings A. Ilie).

ANA ILIE,

Complexul Naţional Muzeal „Curtea Domnească”

Târgoviște, Calea Domnească, nr. 181,

Târgoviște, Romania,

ana_arheo@yahoo.com

LOREDANA NIȚĂ,

Universitatea ,Valahia” din Târgoviște,

Lt. Stancu Ion, 35, 130105, Târgoviște, Romania,

loredana_nita2003@yahoo.com 